\title{
Die Menigte rondom Jesus
}

P J J Botha

(Unisa)

\section{ABSTRACT}

The crowds around Jesus

This article is an exercise in historical imagination. By employing an interdisciplinary approach some facets of the appearance and daily experiences of first century Galilean peasants are discussed. The question, how we should picture Jesus' crowds, thereby becomes a powerful way of opening a window onto the world of the historical Jesus.

\section{INLEIDING}

Die Evangelies vertel dikwels dat ' $\mathrm{n}$ skare mense rondom Jesus vergader het. So, byvoorbeeld, vermeld Markus 2:13 dat "'n hele menigte mense het na Hom toe gekom, en Hy het hulle geleer". Die Evangelies maak duidelik dat die "menigte" 'n belangrike rol in die geskiedenis van Jesus speel. Dit is dus te wagte dat studies aan die tema gewy sal word.

Die meerderheid navorsers het die aandag gefokus op die redaksionele verwerking van die evangelietradisies se verwysings na die skares.' 'n Alternatiewe benadering is om die Evangelies met behulp van narratiewe teorie te ontleed. ' $n$ Besondere insig is dan dat binne die storiewêrelde wat die evangelieskrywers met hulle vertellings skep, die skare dikwels as 'n karakter figureer. In hierdie trant kan die analise van Rhoads en Michie ter illustrasie vermeld word". Gesien as "een" van die karakters wat bydra tot die realisering van die plot van Markus se vertelling, en die karakterisering van Jesus en die uitbeelding van mense se reaksie op Jesus, is die Markaanse skare baie funksioneel. Aan die een kant vertoon hulle mense se groot nood aan Jesus, maar uiteindelik beeld hulle ook mense se verwerping van Jesus uit ${ }^{3}$.

Wat hierdie artikel egter betref, is ek geïnteresseerd in die historiese vraagstelling. Hoe moet ons daardie groep mense, die Galileërs rondom Jesus, in ons geestesoog voorstel? 


\section{OUDERDOM}

Lukas beweer dat Jesus omtrent 30 jaar oud was toe hy "met sy werk begin het", net nadat hy deur Johannes die Doper gedoop is $(3: 23)^{4}$. Vir sy tyd beteken dit dat Jesus nouliks ' $n$ jong man was. In die stede van destyds het minder as ' $n$ derde van die mense wat hulle eerste lewensjaar oorleef het, twintig jaar en ouer gewords. Op die platteland was omstandighede effe beter, maar van die hele bevolking het slegs 'n vyfde veertig jaar of ouer geword. Daar was maar een of twee mense uit elke honderd wat sestig jaar oud geword het.

Die (gemiddelde) lewensverwagting van mense in die eerste-eeuse Mediterreense wêreld was sowat $22-25$ jaar vir mans en so $18-20$ vir vroue $^{6}$. Die gemiddeld was besonder laag omdat so baie mense jonk gesterf het. Wat ons egter goed moet begryp is dat nie veel mense ouer as dertig was nie. Jesus se gehoor, in die algemeen gesproke, was jonger as hy. Die "skare" wat so om hom bymekaar gekom het, het Jesus gesien as 'n ervare persoon; hy het, wat landelike kleinboere betref, die grootste deel van sy lewe agter die rug gehad. Die meeste van die "menigte" rondom Jesus het die vooruitsig van miskien nog tien jaar van lewe gehad?.

Hierdie beramings word bevestig deur die argeologiese vondste van honderde skelette van mense wat in die eerste eeu in Palestina begrawe is by Jerigo, Jerusalem en En Gedi ${ }^{8}$. Dit alles in ag geneem, weet ons dat net sowat tien persent van die bevolking vyftig en ouer geword het. Trouens, soos reeds vermeld, ' $n$ bietjie meer as een persent - 5 uit 400 mense - het maar sestig geword. Toevallig is bykans al die Palestynse gebeentes (vanuit die Romeinse era) wat gevind is van mense ouer as sestig, die van mans. Soos in die res van die eerste-eeuse Mediterreense wêreld het in Palestina die meeste volwasse mans tussen 20 en 29 jaar oud gesterwe. Alhoewel die skeletoorblyfsel aantoon dat sommige vroue (moontlik $20 \%$ van die bevolking) tussen 30 en 39 gesterf het, is dit beter om die tendens in die res van die Romeinse wêreld ook hier te veronderstel: volwasse vroue sterf in hulle vroeë twintigs'. Meer meisies (jong dogters) het doodgegaan as seuns - waarskynlik omdat seuns ' $n$ bietjie beter versorging ontvang het ${ }^{10}$.

Die mense rondom Jesus het hulleself, so in die algemeen beskou, volgens ouderdom gerangskik. Ouderdom, spesifiek in die sin van ouerskap, en nog meer spesifiek vaderskap, was 'n beslissende aanduiding van status. Dit was die vaders van die gemeenskap wat die sê gehad het en dit was die ouer mans wat die naaste rondom Jesus vergader het.

Uiteraard is die kulturele waarde om erns te maak met die oumense, spesifiek die vaders, in Bybelse tye (en ander antieke kulture) verstaanbaar 
teen die agtergrond van kort leeftye en 'n pre-industriële tegnologie. In 'n wêreld wat nie massakommunikasiemedia besit het nie, en waar selfs die skryfkuns skaars was, is dit die ouer geslag wat die gemeenskap se tradisies en waardes, se geskiedenis en insigte, kan waarborg. In daardie wêreld was jongmense die afgeskeeptes en die misbares. Ter wille van oorlewing moes die gemeenskap wel baie kinders hê, maar terselfdertyd moes hulle aan die oumense geweldig baie gesag toeken. Die ouer geslag was die bron van identiteit en kennis.

Dit is die mooi kant van die verheerliking van die ouer geslag. Die ander kant is dat dit gewoon die noodwendige uitloop is van 'n volskaalse patriargie. "Eer jou oueres" het in so 'n konteks 'n materiële begronding en magsbasis wat spesifiek ouer mans bevoordeel. Dié stelsel sorg dat mans altyd die voordeel kry en dat hulpbronne en eer altyd onregverdig verdeel word. Dit hang ook saam met 'n wêreldbeeld wat kinders en vroue as van nature boos beskou"1. Dit was 'n wêreld waar "liefde" en die roede een en dieselfde ding was. "Buig sy nek en slaan hom behoorlik terwyl hy jonk is" het die spreekwoord gesêt2. Kinderlike gehoorsaamheid in Jesus se wêreld was geen ligtelike sakie nie, met verreikende psigiese en sosiale implikasies ${ }^{13}$.

\section{GESONDHEID}

Ons kan nog heelwat meer sê oor dié Galilese mense wat Jesus self "innig jammer gekry het, want hulle was soos skape wat nie 'n wagter het nie" (Mk 6:34). 'n Tipiese groep kleinboere, wat so bymekaar gestaan het, was deurspek met siektes en kwale.

Alle ouer mense het gely aan tandverrotting - trouens, ons kan skat dat sowat $5 \%$ van sterftes per jaar die gevolg van tandverrotting was ${ }^{14}$. Tipies het mense ouer as dertig ook aan osteo-artritiese kwale gely's.

Vir hierdie mense was 'n klomp toestande wat ons as kwale sou beskryf so alledaags en deel van die lewe dat dit hoegenaamd nie gesien is as siektes nie 16 . Dit is nou dinge soos hoes, anemie, masels, verkoue en oogkwale. Selfs tuberkulose is aanvaar as bloot deel van die lewe. Oogsere en katarakke was baie, baie algemeen. Waaroor hulle wel behep was, was velsiektes en bloeding. ' $n$ Velsiekte is beskou as die uiterlike manifestasie van "onreinheid", en dit het nie saak gemaak of die velsiekte frambosesiekte, ekseem, psoriase of selfs sommer net 'n droë skilfervel was nie 17 .

Parasiete was ook 'n baie algemene verskynsel. Trouens, meer as die helfte van die kamme en haarversiersels wat opgegrawe is dra duidelike getuienis van luis-infestasies ${ }^{18}$. Nog meer verreikend is die feit, afgelei 
vanuit fekale oorblyfsels, dat ingewandsparasiete besonder algemeen was veral hidatides en lintwurms ${ }^{19}$.

Dan weet ons ook dat die menigtes meesal wan- en ondervoed was ${ }^{20}$. Die tweede-eeuse medikus, Galenus, se tiperende beskrywing gee ons 'n goeie indruk van omstandighede op die platteland:

Die hongersnode wat bykans ononderbroke oor baie jare onder talle volke in die Romeinse ryk voorkom, maak duidelik, vir enigiemand wat nie heeltemal onnosel is nie, tot watter mate ongesonde kos siektes veroorsaak. Onder baie van die gemeenskappe in die Romeinse ryk is dit die gebruik dat die stadsbewoners net na die oes genoeg graan versamel en dan stoor vir die volgende jaar, en om dan wat oorbly te los vir die plattelanders, dit wil sé verskillende soorte peulplante, maar dan word hiervan ook nog ' $n$ groot deel stad toe gevat. Die plattelanders verorber al die peulplante tydens die winter en moet dan van ongesonde kos gebruik maak in die lente. Hulle eet dan takkies en uitlopers van bome en bossies, en bolle en wortels van onverteerbare plante; hulle word versadig van wilde kruie en gekookte groen gras'2!

Terwyl Jesus die "menigte" geleer het, het hy uitgekyk op mense wat krom, honger, siek, en pessimisties was. Vir hierdie mense was die alledaagse belewenis van die lewe spanningsvol, vreesaanjaend en onverstaanbaar. Wat 'n tipiese "skare" rondom Jesus sou betref, was die lewe kort, vol siektes en uitsigloos.

\section{KLEINBOERE}

Verskeie kere in die betoog sover is daar na die "menigte" rondom Jesus as kleinboere verwys. Alvorens ek meer uitwy oor hoe ons dié mense kan visualiseer, moet die term "kleinboer" belig word. Dit beteken ons moet aandag gee aan die samelewingstruktuur van destyds.

Die begrip "kleinboer" word hier gebruik met 'n spesifieke betekenis, naamlik landvolk (Engels: peasants). Die hele ekonomie van die Mediterreense wêreld was afhanklik van die landbou, 'n agrariese samelewing dus22. Daar was, vanuit 'n sosio-ekonomiese oogpunt bekyk, eintlik net twee "klasse" mense: die klein groepie aristokrate (sowat 2 na 3 persent van die totale bevolking) en die groot massa kleinboere (sowat 8085 persent van die bevolking). 'n Kleinerige groepie mense ( \pm 8 persent) kan ons beskryf as die "ondersteunersklas" - dit is nou mense soos priesters, skrifgeleerdes, handelaars, weermagoffisiere, en so meer. Baie boeke oor die bybelse wêreld verwys (heeltemal foutewielik) na 'n sogenaamde middel-klas. Daar was nie so-iets nie; die naaste daaraan is die groepie mense van hierdie "ondersteunersklas". Dan was daar nog die "verwerplikes": diegene wat nie meer deel was van 'n familie of huishouding nie ${ }^{23}$. Dit wil sê, mense met ongeneeslike kwale of 
geestesversteurdes wat nie deur 'n huishouding aanvaar word nie, of nie meer toegang tot 'n familie het nie; die reddeloses en bedelaars (sowat 3-5 persent van die bevolking). Slawe was 'n algemene verskynsel, maar hulle situasie is in 'n sekere sin nogal ingewikkeld. Onder die "menigtes" rondom Jesus was slawe weliswaar nie afwesig nie, maar daar sou na alle waarskynlikheid nie juis baie van hulle daar teenwoordig gewees het nie ${ }^{24}$.

Die bevolkingsverspreiding van destyds staan dus in skrille kontras met die van 'n geïndustrialiseerde samelewing. Die oorgrote meerderheid mense het op die platteland gebly en klein stukkies grond bewerk. Daar was in die antieke Mediterreense wêreld maar 'n handvol werklike stede (wat ons nou 'n stad sou noem). In antieke Palestina kan ons eintlik net Jerusalem 'n stad noem. Dorpe was baie meer algemeen, maar in Galilea kan ons net plekke soos Tiberias en Sepporis beskou as werklike dorpe (inwonertalle van so om-en-by 10000 ). Die werklike bevolking van Palestina was versprei oor die platteland: 'n verskeidenheid kleindorpies (elk met 'n paar honderd inwoners, en dan eerder minder as meer) en gehuggies. Hierdie kleindorpies was so tien na twintig kilometer uit mekaar versprei (ongeveer drie ure se loop van mekaar af). Hierdie dorpies wat die Galilese landskap gekenmerk het, se inwoners het gewissel van so dertig tot tweehonderd-en-vyftig gesinne: vyf of ses tot vyftig of sestig (hier-en-daar, die uitsondering, sewentig of meer) huise ${ }^{25}$. Rondom die kleindorpies was die landerye geleë, opgedeel in klein lappies grond. Daar was ook groot landgoedere wat an die elite behoort het. Werkers is gehuur vanaf die omliggende dorpies om hierdie landerye te bewerk. Veral sedert die tyd van Herodes het meer en meer kleinboere se eiendom in die hande van groot grondbesitters beland. Party kleinboerfamilies het ook familieplase besit; maar ook dié het algaande begin verdwyn deurdat die grondbaronne meer en meer van die plase oorgeneem het, veral sedert die laaste jare van Antipas se regeertyd ${ }^{26}$.

Om te beklemtoon dat Jesus se gehoor uit Galilese kleinboere bestaan het, bring die insig mee dat die "menigte" bestaan het uit mense wat swaar gekry het. Die een enkele faktor wat die eerste-eeuse kleinboere se lewe en wêreldbeeld bepaal is die feit dat hulle vasgevang was in ' $n$ oorlewingstegnologie ${ }^{27}$. Die tipiese situasie van 'n kleinboer in 'n agrariese kultuur is nie ' $n$ aangename een nie, des te erger in die eerste-eeuse Mediterreense wêreld ${ }^{28}$. Kos (en water) het hulle gedagtes meesal oorheers. Die grootste dilemma was egter dat sulke kleinboere vasgevang was in ' $n$ onbreekbare siklus van arbeid, belasting en skuld. Die aristokratiese en hierargiese waardestelsel van die destydse kulture (en spesifiek dan van die situasie in Romeinse Palestina) het noodwendig veroorsaak dat klein- 
boere geëksploiteer moes word - dikwels tot op die uiterste van hulle vermoëns ${ }^{29}$. Hierdie mense was oorwegend moeg en honger, en al te bewus van die onontkombaarheid van skuld, van die voortdurende druk om te werk vir die voordeel van ander.

"He comes as yet unknown into a hamlet of Lower Galilee. He is watched by the cold, hard eyes of peasants who have lived long enough at subsistence level to know exactly where the line is drawn between poverty and destitution. $\mathrm{He}$ looks like a beggar, yet his eyes lack the proper cringe, his voice the proper whine, his walk the proper shuffle. He speaks about the rule or kingdom of God and they listen as much from curiosity as anything else. They know all about rule and power, about kingdom and empire, but they know it in terms of tax and debt, malnutrition and sickness, agrarian oppression and demonic possession. What, they really want to know, can this kingdom of God do for a lame child, a blind parent, a tormented soul screaming its tortured isolation among the graves that mark the village fringes?" 30

\section{HOE HET SO 'N MENIGTE RONDBEWEEG EN VER- GADER?}

Dit is vanselfsprekend dat die menigte gestap het. Daar was destyds geen openbare vervoermedia nie; alleenlik die heel rykes is gedra of vervoer.

Omdat Jesus meesal in die somermaande sou rondbeweeg het - die tyd van ploeg, saai en oes - is dit vanaf die dorpies en die "lande" rondom die dorpies wat die mense gestroom het om Jesus aan te hoor. En omdat ons weet hoe ver sulke "nuuswaardige" gebeure mense in landelike, preindustriële situasies se aandag sodanig trek ${ }^{31}$ dat hulle sal kom kyk, kan ons selfs skat hoeveel mense na alle waarskynlikheid bymekaargekom het om Jesus aan te hoor: so 'n honderd na tweehonderd mense.

'n "Skare" destyds verwys eintlik na ses groepe, wat dan ondermekaar verdeel in die volgende groeperinge: ou mans, jong mans, seuns, ou dames, volwasse vroue (getroude moeders) en jong vroue (ongetroude, maar hubare meisies) ${ }^{32}$. Klein kindertjies (so 6 en jonger, meesal seuns siende dat dogtertjies tuis gelaat word) hardloop rond en bont; raak maklik weg of bly maklik agter op 'n plek omdat niemand oor hulle bekommerd is nie. Selfs ouer seuns kon maklik so "verdwaal" as een nie by sy groep bly nie, of nie goed deur sy groep aanvaar word nie.

'n Man het eerder saam met sy ouderdomsgroep gestap; dit was baie slegte maniere om saam met jou vrou te stap as daar 'n groep mense (mans en vroue) betrokke was. Vroue het weer saam met mekaar beweeg, en altyd agter die mans ${ }^{33}$. Selfs wanneer 'n skare deur soldate gekonfronteer is, was dit goed moontlik dat die mense die groepering volgens geslag en 
ouderdom sou handhaaf. Weer eens word ons bewus van hoe drasties patriargaal daardie wêreld was.

Die meeste van die jonger getroude vroue was swanger ${ }^{34}$.

Wanneer ons dink oor dié mense wat so naderstap om meer van Jesus uit te vind, moet ons in gedagte hou dat heelparty van hulle (jonk en oud) swaar loop; baie gebruik kieries. Skeletoorblyfsels wys ons dat baie mense ledemaats- en gewrigsprobleme gehad het: bo-en-behalwe siektes het onvoldoende mediese sorg en onbehoorlike spalkings gesorg dat gebreekte enkels, bene, arms en handbeentjies (dikwels alledaagse gebeure) verreikende impak gemaak het op die mense se liggame.

' $n$ Ander interessante aspek om te probeer visualiseer is houding en stapstyle. Die aristokratiese jongmans is van kleinsaf geleer om met grootdoenerig te stap (om te swagger) terwyl ouer aristokrate met baie status weer stadig en afgemete gestap het. 'n Koning en 'n generaal het met lang treë geloop. Van die laer stande is verwag om met korter treë te loop. Jongmense en vroue moes met neergeslane oë loop as daar mans naby was. Statuserkenning was 'n fundamentele saak in die antieke wêreld, en met jou kop, oë en hande moes mens te kenne gee wanneer jy in die geselskap is van mens se meerderes: 'n geboë hoof, wegkyk en oop hande 35 .

Wanneer Jesus naby 'n groter sentrum rondbeweeg het sou die "menigte" moontlik meer mense behels het. Die interessante is egter dat die Evangelies geen aanduidings gee dat Jesus ooit opgetree het in die groter plekke nie. Volgens die evangelieskrywers het Jesus sy aktiwiteite beperk tot die platteland en die kleindorpies; die enigste stad wat hy besoek het was Jerusalem, aan die einde van sy lewe.

Wanneer Jesus in 'n dorpie oorgebly het, kan ons verwag dat na 'n dag of drie, mense vanuit die omgewing en veral vanaf die naaste buurdorpies sou kom om Jesus aan te hoor. Sulke groepies - eintlik families en/of huishoudings - sou laatmiddag oorstap, en by vriende/familie oornag. Die vroue wat lede is van so 'n groep kom laaste aan en vertrek weer eerste. Die eintlike doel van hulle besoek, om Jesus te spreek, sou gewoonlik oorstaan tot die volgende dag of selfs later: die reëls van resiproke verpligtinge maak dat mens alle sosiale gebeure op die "lang" manier doen ${ }^{36}$. Om by Jesus uit te kom, sou hulle deur middel van hulle bekendes werk. Andersins sou hulle deur die loop van die (volgende) dag probeer het om by Jesus se gasheer uit te kom of om met een van Jesus se dissipels te praat om uiteindelik die geleentheid te kry om deel te raak van die groepie mense reg rondom Jesus. 


\section{HOE HET HULLE GELYK EN HOE WAS HULLE AANGE- TREK?}

Joodse (volwasse) mans in die tyd was 160 tot 165 sentimeter lank, en vroue 150 tot 156 sentimeter. Hulle liggaamsbou is tipies soos die van korterige, stewige mense, en besonder kenmerkend was breë voorkoppe ${ }^{37}$.

Omdat die skare rondom Jesus hoofsaaklik uit kleinboere bestaan het weet ons dat hulle eenvoudig en prakties aangetrek was; die klein groepie aansienlikes wat sou oorgestap het, was opsigtelik anders. Die standverskille tussen die kleinboere en die vername mense was sigbaar in. voorkoms, versorging, liggaamshouding en veral in kleredrag38.

Kleredrag het nogal ' $n$ besondere rol in die antieke samelewings gespeel. Destyds was klere $66 \mathbf{k}$ aanduiding van status en posisie in die samelewing. Veral hooftooisels en die kleure van mens se kleding het onmiskenbaar aangedui watter aansien mens geniet. In die algemeen gesproke, het mense dikwels net twee stelle klere besit. Daar was 'n stel klere vir alledaagse gebruik en 'n tweede stel klere vir feesgeleenthede ${ }^{39}$. Onder gewone mense, en veral onder Palestynse kleinboere, was dit selfs algemeen om net 'n enkel stel klere te besit en om met geleende klere feesgeleenthede by te woon ${ }^{40}$.

Die basiese kleredrag het bestaan uit 'n lendedoek (wat ons ook 'n onderrok kan noem), 'n lyfrok (die sogenaamde "onderkleed") en 'n mantel (die sogenaamde "bo-kleed"). Een of ander hoofbedekking het die kleding voltooi. Skoeisel (sandale) was opsioneel, en dikwels die lendedoek ook, afhangende van omstandighede.

Die lendedoek was die heel minimum van klere, dikwels (veral in die somermaande) die werkdrag van mans. Dit was 'n strook materiaal wat om die middellyf vasgemaak is en na gelang van omstandighede tussen die bene deur gevou is.

Die lyfrok was eintlik 'n lang reghoekige stuk kleed wat soos 'n sak aanmekaar gewerk is. ' $n$ V-vormige opening is vir die kop ingesny en in die hoeke is daar snitte gemaak vir die arms. Moue is slegs gemaak vir spesiale klere of vir die klere van welaf mense. Klere is nie in groottes gemaak nie; die grootte van die stuk lap het die grootte van die kleed bepaal. Materiaal is letterlik van die weefraam afgehaal en klere van gemaak. Om dit te sny of verder te verwerk het dit te duur gemaak en was 'n vermorsing van tyd en energie, want kledingstukke moes veeldoelig wees asook maklik vir verskillende mense kon pas (hoe meer hoe beter).

'n Lyfrok is gewoonlik gemaak van twee stukke lap, en die ideaal was dat die naat op heupvlak moes lê. 'n Naatlose lyfrok was nie 
noodwendig 'n spoggerige kleed nie ${ }^{41}$. Die lyfrok van mans was kort (op of net bokant die knieë), die van vroue lank, tot by die enkels. Dit is van wol, linne, katoen of bokhaar gemaak, dikwels is die stowwe gemeng met die spin en weef 42 .

'n Stuk tou of lyfgordel van lap of leer is gebruik om die middellyf. Die gordel was meer as net ' $n$ lyfband. Omdat dit gewoonlik breed was, is dit so gevou dat dit ook kon dien as beursie en selfs as 'n handsak (soos 'n "moonbag") waarin mens enigiets van jou mes tot kos kon bêre. As Jesus vir sy dissipels die opdrag gee om nie 'n "beursie" saam te neem nie (Mk $6: 8$ ) is die vertaling 'n bietjie misleidend; Jesus sê eintlik vir sy dissipels hulle moenie 'n gordel saamvat nie.

Wanneer dit nodig was om meer vrylik te beweeg het mens die pante van jou lyfrok opgelig en in die gordel ingesteek. Beide mans en vrouens het so gemaak. Joodse waardes was maar min gepla oor 'n kaal bolyf of selfs kaal bene; dit was eintlik net kaal geslagsdele wat vernedering veroorsaak het, veral mans s'n. Verder moes vrouens hulle gesigte en veral hulle hare bedek.

Bo-oor die lyfrok is die mantel (die "bo-kleed") gedra. Die mantel was 'n lang strook materiaal wat los om die liggaam gedrapeer is. 'n Mantel van dik wolstof was 'n gesogte item, want snags het mens jou mantel as kombers gebruik. In die winter en in koue gebiede was jou mantel nogal 'n belangrike kledingstuk! Onder kleinboere was daar dikwels net een mantel in die huisgesin ${ }^{43}$.

Die mantelkleed is partykeer by die skouers vasgewerk sodat dit "aangetrek" kon word in plaas van om die lyf gedraai te word. Ryk mense - maar ook diegene wat een as geskenk ontvang het of dit op een-of-ander manier in die hande gekry het - het ' $n$ japonagtige mantel met moue besit. Sulke mantels was baie gesog, dit was die toppunt van modieuse kleredrag.

'n Dwarspen is gebruik om die mantel vas te maak. So 'n dwarspen was so 10 tot 18 sentimeter lank en het 'n oog gehad om-en-by tweederdes van die punt af; die boonste gedeelte van die pennetjie was gedraai, of met riffels gemaak. Met behulp van die gaatjie is die pen aan die een punt van die materiaal vasgewerk, 'n toutjie is an die ander punt van die materiaal vasgewerk. As die mantel aangetrek is en die pen vasgesteek is, is die toutjie rondom die riffels van die pen vasgedraai. Dwarspenne is van brons of goud gemaak ${ }^{44}$.

Indien daar met die weef van die materiaal strepe ingeweef is, is die kleed altyd so gemaak dat die strepe vertikaal is. Mansklere was gewoonlik bont en vroue s'n eenkleurig. Strepe dui status aan, dus het pa's en oupas die klere met strepe gedra. Mansklere moes verkieslik nie, soos die van 
vrouens en kinders s'n, ten volle gekleurd gewees het nie. Vroue het nie wit klere gedra nie ${ }^{45}$. Klere met strepe en klere van ten volle gekleurde materiaal wys heen na mans- en vroueklere onderskeidelik; 'n onderskeid wat belangrik was vir destydse waardes.

Baie van die mans se klere het nie eintlik some gehad nie terwyl die vrouens hulle some versier het, veral die rondom die kante van die V-nek. By verre was die algemeenste kleure van die kleinboere se kledingstukke skakerings van bruin en grys ${ }^{46}$. Om lappe met kleure te maak is die materiaal gekleur voor dit geweef is, en naas groen en rooi, was dit geel, dofblou en dofrooi wat gebruik is ${ }^{47}$. Pers en blou was baie gesog, maar meer kenmerkend van welaf mense se $k^{2}{ }^{48}$. Dit was nogal moeilik om helder kleure in materiaal te verkry, en nog moeiliker om sulke klere helderkleurig te hou na baie dra en was.

Meesal was die soom van die mantel ongesoom. Iemand wat egter streng volgens die Farisese leefwyse geleef het, het 'n breë soom gehad met blou tossels aan die vier hoeke daarvan. Jesus het sulke tossels aan sy mantel gedra (Mark 6:56) ${ }^{49}$.

Hoofbedekkings het gewissel van 'n kleinerige reghoekige stuk lap wat met 'n toutjie in posisie gehou is, tot lang en veelkleurige tulbande. Kopdoeke is gedra rondom die kop, nek en skouers, maar vroue het ook hulle gesigte toegedraai. Gevlegte koorde of helder veelkleurige materiaal wat die kopdoeke vashou was aanduidings van status.

Onder die kleinboere van Galilea was gladgeskeerde mans 'n ongewone gesigso. Die Romeinse mode was 'n kort, ronde baard met skoongeskeerde wange en ken; die tradisionele Joodse mode was 'n vol, ronde baard wat rondom die mond geskeer word (die lippe duidelik sigbaar). Onder die gewone mense is baarde net versorg ter voorbereiding van feestelike geleenthede, en 'n kammetjie en skerp mes het hiervoor gedien. Aansienlikes en dorpenaars met status wat lang baarde gedra het, het hulle baarde gekrul. (Snorre met 'n skoongeskeerde gesig was geheel-en-al onbekend; dié mode sou eers baie eeue later inslag vind). Vanuit destydse literatuur kan ons aflei dat mens 'n man met status en 'n kleinboer, handearbeider (en ook slawe) kon uitken volgens die versorging van hulle baarde.

Die sandale wat mense gedra het was dikwels eenvoudig: 'n voetpatroon is op beesvel uitgesny; 'n riempie (of toutjies) langs die groottoon was die basis om die sandaal aan die voet vas te bind. Skoene was nie onbekend nie, maar die enkeles wat argeologies gevind is maak duidelik dat dit maar seldsaam was en as 'n luukse artikel beskou is. Skoene van leer sou ons sommer pantoffels genoem het; geen mens kon dit buitekant 
gebruik nie. Meer duursame skoene is van hout gemaak. In Jesus se wêreld was skoeisel net regtig belangrik vir feestelike geleenthede.

Baie welaf mense het ' $n$ groter verskeidenheid klere besit. Wat sulke mans betref: halsdoeke, musse en hoede, asook, naas die gebruiklike kort lyfrokke, ook lang lyfrokke en lyfrokke met moue het deel uitgemaak van die verskeidenheid. Broeke was nie onbekend nie, maar selde gebruik en as ongemaklik en bowendien ' $n$ mors van materiaal beskou. Welaf vroue het ook ekstra lang en kort lyfrokke besit en 'n verskeidenheid van gordels.

Sommige "beroepe" of ampte het ekstra of spesiale klere vereis. So, byvoorbeeld, moes priesters 'n addisionele lang lyfrok hê, en 'n spesiale linneskouerkleed wat bo-oor die mantel gedra is.

Ons kan ons dus voorstel dat die menigte rondom Jesus meesal gekleed was in hulle lyfrokke. Die meeste se klere was verweer en gelap. Sommiges, wat van vêr af gekom het, het hulle mantels aangehad en ander mans, wat sommer van digby af uit nuuskierigheid nader gestap het, het met kaal bolywe rondgestaan. Heelparty was kaalvoet, maar almal het kopdoeke aangehad.

\section{SAMEVATTEND}

In hierdie studie word die moontlikhede van interdissiplinêre navorsing geillustreer. 'n Verskeidenheid insigte vanuit argeologie, sosiologie en antropologie word ingespan om die historiese verbeelding te aktiveer.

Die onderliggende aanname is dat, in plaas daarvan om te strewe om 'n sogenaamde "boodskap" vanuit 'n "teks" te onttrek, dit beter is om historiese verstaan te bewerkstellig. Dit loon ons om te vra na die mense, die mense in, agter, rondom die tekste. Sodoende maak 'n eenvoudige vragie - hoe het die menigte rondom Jesus gelyk? - 'n wye venster oop na die wêreld van die historiese Jesus.

Deur die venster gewaar ons eenvoudige en uitgebuite mense, met kwale en vrese. Ons kry egter ook respek vir hulle menslikheid, want hulle het - onbewus van óns waardes, perspektiewe en voorregte - tog oorlewe en met waardigheid hul bes gedoen.

Ten slotte: dit is my bedoeling dat ons besef hoe die geweldige rykdom van lewe en denke wat moderne historiese verstaan ontsluit een van die grootste verrykings van teologiese verstaan kan wees. Één so 'n waardevolle bydrae is om nie anakronisties en etnosentries oor die mense (van die verlede) wat ons as belangrik vir ons eie leer en lewe beskou, te dink nie. 


\section{NOTAS:}

1 Ter illustrasie van dié benadering: "The image of the crowds gathering to and around Jesus is a Markan creation, for they are mentioned for the most part around the edges of the stories and fill in the background against which all of the foreground events of the gospel take place", B L Mack, A myth of innocence: Mark and Christian origins, Philadelphia 1988, 230. Die "skare" verkry dus, so gesien, 'n teologiese inhoud binne die evangelieverhaal; 'n goeie weergawe van sulke redaksionele analise is, byvoorbeeld, $\mathrm{R}$ Pesch, Das Markusevangelium. 1. Teil: Einleitung und Kommentar zu Kap. 1,1-8,26, Freiburg 1976, 146-49.

2 D Rhoads and D Michie, Mark as story: an introduction to the narrative of a gospel, Philadelphia 1982.

3 Rhoads and Michie, Story, 134-35. Kyk ook E S Malbon, “Disciples/crowds/ whoever: Markan characters and readers", Novum Testamentum 28 (1986), 104 30. 'n Baie goeie uiteensetting van die teorie van karakterisering in vertellings is S Chatman, "Characters and narrators: filter, center, slant, and interest-focus", Poetics today 7 (1986), 189-204.

4 Lukas maak duidelik dat dit 'n benaderde getal is. Dit kan wees dat Dawid se ouderdom toe hy koning geword het (2 Sam 5:4) Lukas beïnvloed het. Die afrond van ouderdomme (benader tot naaste skatting in veelvoude van 5) is 'n tipiese verskynsel van kulture met beperkte literariteit, soos die van die Romeinse ryk: R P Duncan-Jones, "Age-rounding, illiteracy and social differentiation", Ciron 7 (1977), 333-53.

5 Vergelyk T F Carney, The shape of the past: Models and antiquity, Lawrence 1975, 88; G Lenski, J Lenski, and P Nolan, Human societies: an introduction to macrosociology, (6th ed), New York 1991, 173; G Hamel, Poverty and charity in Roman Palestine, first three centuries C.E., Berkeley 1990, 53-54.

6 R Stark, "Antioch as the social situation for Matthew's gospel", in: Social history of the Matthean community: cross-disciplinary approaches, edited by D L Balch, Minneapolis 1991, 195; D A Fiensy, The social history of Palestine in the Herodian period, Lewiston 1991, 97-98; Peter Brown, The body and society: men, women and sexual renunciation in early Christianity, London 1988, 6.

7 B J Malina and R L Rohrbaugh, Social-science commentary on the synoptic gospels, Minneapolis 1992, 211, 305.

8 B Arensburg and P Smith, "The Jewish population of Jericho 100 B.C. -70 A.D", PEQ 115 (1983), 133-39; P Smith and J Zias, "Skeletal remains from the late Hellenistic French Hill Tomb", IEJ 30 (1980), 109-15; R Hachlili, B Arensburg, P Smith, and A Killebrew, "The Jewish necropolis at Jericho", Current Anthropology 22 (1981), 701-02; N Haas, "Anthropological observations on the skeletal remains from Giv"at ha-Mivtar", Israel exploration journal 20 (1970), 38-59. Vergelykende inligting (18de eeuse Bedoeine), M S Goldstein, B Arensburg, and H Nathan, "Pathology of Bedouin skeletal remains from two sites in Israel", American Journal of Physical Anthropology 45 (1976), 621-40.

9 Om verskeie redes bly vroue-skelette nie so goed behoue soos die van mans s'n nie - en statistiese ontledings is dus wat vroue betref minder betroubaar. Vyftig 
persent van die grafstene vir vroue in Noord-Afrika tydens die vroeë Romeinse ryk dui ' $n$ leeftyd van minder as 23 jaar aan. Die groot krisis vir destydse vroue was die druk om soveel as moontlik kinders te hê; dit was 'n wêreld "grazed thin by death", Brown, $a w, 6$.

10 In die res van die eerste-eeuse Mediterreense wêreld het vroue meesal in hulle vrugbare jare gesterwe, so om-en-by 30 maar dikwels voor die ouderdom van 20. P Garnsey and R Saller, The Roman empire: economy, society and culture, Berkeley 1987, 138; R Garland, "Greek geriatrics", History Today 37/9 (1987), 12. Vir gegewens oor spesifiek Palestina tydens die Romeinse ryk, Arensburg and Smith, a w, 1983, 133. Kyk ook Goldstein, Arensburg, and Nathan, "Pathology", 632-33.

11 Vir 'n uiteensetting van die parria porestas in Joodse konteks: L J Archer, Her price is beyond rubies: the Jewish woman in Graeco-Roman Palestine, Sheffield 1990, 17-63, 207-39. J Neusner, Method and meaning in ancient Judaism, Missoula 1979, 79-100 toon aan hoedat 'n polêre man/vrou ideologie die Misjna beheer, ' $n$ voortsetting van die (Levietiese) aanname dat vroue abnormaal en 'n bedreiging vir "heiligheid" is.

12 Sirag 30.1-13, spesifiek vers 12. Kyk ook Spreuke 13:24, 22:13-14, 29:15, 19. Dogters was ' $n$ las en beskou as 'n onuitputlike bron van skande: P J J Botha, "Folklore, social values and life as a woman in early Christianity", Southern African Journal for Folklore Studies 3 (1992), 1-14; L J Archer, "The virgin and the harlot in the writings of formative Judaism", History Workshop: $A$ Journal of Socialist and Feminist Historians 24 (1987), 1-16; J J Pilch, "'Beat his ribs while he is young' (Sir 30:12): a window on the Mediterranean world", BThB 23 (1993), 104-05.

13 Pilch, "Beat his ribs"; Archer, Her price, 83-101; J Barr, "Abba isn't 'daddy'”, JThS 39 (1988), 28-47; B J Malina, The social world of Jesus and the Gospels, London 1996, 67-96.

14 Stark, "Antioch", 195 n 2. Cf A rensburg and Smith, $a w, 1983$, 133; Hachlili, Arensburg, Smith, and Killebrew, a w, 1981, 701; Goldstein, Arensburg, and Nathan, $a w, 1976,625-26$ en J Zias and K Numeroff, "Ancient dentistry in the eastern Mediterranean: a brief review", IEJ 36 (1986), 65-67.

15 Arensburg and Smith, “Jewish population", 134-36. Cf. Goldstein, Arensburg, and Nathan, $a w, 1976,628-32$.

16 Kyk P Worsley, "Non-Western medical systems", Ann.Rev.Anthropol. 11 (1982): 336 en G M Foster, "Disease etiologies in non-Western medical systems", American Anthropologist 78 (1976), 773-82. Vir 'n oorsig or gesondheid in die eerste-eeuse Mediterreense wêreld met die klem op teoretiese verstaansprobleme: P J J Botha, "Health and healing in New Testament times: historical understanding and the health care debate", Health SA Gesondheid 1/2 (1996), 3-11.

17 Daar is 'n omvangryke diskussie or die aspekte beskikbaar: $\mathrm{K}$ Manchester, "Tuberculosis and leprosy in antiquity: an interpretation", Medical History 28 (1984), 162-73; H C Kee, Medicine, miracle and magic in New Testament times, Cambridge 1986, 10-11; C J Hemer, "Medicine in the New Testament world", in: B Palmer (ed), Medicine and the Bible, Exeter 1986, 77; Mary Douglas, Purity and danger: an analysis of the concepts of pollution and taboo, 
London 1966, 41-72; J Zias, "Death and disease in ancient Israel", Biblical Archaeologist 54/3 (1991), 149-52; G Lewis, "A lesson from Leviticus: Leprosy", Man 22 (1987), 593-612; E V Hulse, "The nature of Biblical 'leprosy' and the use of alternative medical terms in modern translations of the Bible", PEQ 107 (1975), 87-105; H Eilberg-Schwartz, The savage in Judaism: an anthropology of Israelite religion and ancient Judaism, Bloomington 1990, 177-216; C R Kazmierski, "Evangelist and leper: a socio-cultural study of Mark 1:40-45", NTS 38 (1992), 37-50.

18 Die voorwerpe is by Qumran, Masada, Murabba'at en in die Negev gevind: Zias, $a w, 1991,148$.

19 J Cahill, K Reinhard, D Tarler, and P Warnock, "Scientists examine remains of ancient bathrooms", Biblical Archaeology Review 17/3 (1991), 64-69; Zias, a $w, 149$. Ingewandsparasiete is ' $n$ belangrike oorsaak dat talle mense anemies moes gewees het.

20 Hamel, $a w, 54-56$. Vergelyk die "highly precarious position of the ancient Greek peasantry" wat uiteengesit word in T W Gallant, Risk and survival in ancient Greece: reconstructing the rural domestic economy, Cambridge 1991, 60-110.

21 Galenus De rebus boni malique suci 1.1-3 (Aangaande goeie en slegte kos). Teks: C G Kühn (ed) Claudii Galeni opera omnia vol 6 (Nachdruck, Hildesheim, Georg Olms, 1965), 749-51.

22 Vanuit makrososiologiese oogpunt beskou word onderskei tussen industriële en pre-industriële samelewings. Pre-industriële samelewings manifesteer in primitiewe, tuinboukundige (horticultural) en agrariese gemeenskappe. Lenski, Lenski, and Nolan, $a w, 1991,87-201$ bied 'n handige inleiding. Wat die Romeinse ryk betref: Garnsey and Saller, The Roman empire: economy, society and culture, 43-46; $\mathrm{H}$ Forbes and L Foxhall, "Ethnoarchaeology and storage in the ancient Mediterranean: beyond risk and survival", in: Food in antiquity, edited by A Davidson, Exeter 1995, 70-71 en veral M I Finley, The ancient economy, (2d ed), London 1985. Wat Romeinse Palestina betref, kyk Z Safrai, The economy of Roman Palestine, London 1994, 104 vv en spesifiek vir Galilea, R A Horsley, Galilee: history, politics, people, Valley Forge 1995, 202-21. Verskeie van die implikasies vir Nuwe Testament wetenskap wat erns maak met die werklikhede van 'n agrariese samelewing word verken deur D E Oakman, "The countryside in Luke-Acts", in: J H Neyrey (ed), The social world of LukeActs: models for interpretation, Peabody 1991, 151-79; R L Rohrbaugh, The biblical interpreter: an agrarian Bible in an industrial age, Philadelphia 1978 en J D Crossan, The historical Jesus: the life of a Mediterranean Jewish peasant, Edinburgh 1991, 89-224.

23 Uiteraard is my voorstelling ietwat vereenvoudigd; die punt is om die konteks van Jesus in Galilea te tipeer. Vollediger uiteensettings: Lenski, Lenski, and Nolan, a w, 1991, 195-196; Ramsay MacMullen, Roman social relations: 50 B.C. to A.D. 284, New Haven 1974, 1-56; D E Oakman, "The ancient economy in the Biblen, Biblical Theology Bulletin 21 (1991), 34-39; Anthony J Saldarini, Pharisees, scribes and Sadducees in Palestinian sociery, (reprint 1988), Edinburgh 1989, 35-49. 'n Gedetailleerde ondersoek oor die sosiale struktuur van Herodiaanse Judea en Galilea is gedoen deur D A Fiensy, The social history of Palestine in the Herodian period, Lewiston 1991, 155-76. 
Vir ons, vandag, is daar veral twee probleme wanneer daar gepoog word om oor slawe tussen die mense rondom Jesus te praat: "It is generally rather difficult to differentiate between slaves and free workers", Safrai, Economy, 334. Verder, verslawing het gewoonlik met ontheemdheid gepaardgegaan: slawe is met ander woorde weggeneem vanuit Galilea (cf. Horsley, Galilee, 90). Slawe was 'n "uitvoerproduk" van Palestina: Vergelyk Safrai, Economy, 395.

25 Uitstekende bespreking van hierdie aspekte: Safrai, Economy, 17-103. 'n "Huis" verwys na 'n klompie vertrekke wat 'n binnehof deel en saam van die buitewêreld afgegrens is - 3 tot 5 geslagte woon saam in 'n huis, $S$ Guijarro, "The family in first-century Galilee", in: Constructing early Christian families: family as social reality and metaphor, edited by H Moxnes, London 1997, 4265.

26 Meer oor die omstandighede in eerste-eeuse Galilea by R A Horsley, Archaeology, history, and society in Galilee: the social context of Jesus and the rabbis, Valley Forge 1996; S Freyne, "Galilee (Hellenistic/Roman)", ABD 2 (1992), 895-99. Daar moet gewaak word teen die neiging om alle sosio-ekonomiese kwale in eerste-eeuse Palestina aan die "bose" Herodes die Grote se "diktatuur" toe te skryf. Dié tipe vereenvoudiging sluit die groot verskeidenheid faktore wat oor 'n lang tyd bygedra het tot die rampe van veral Judea, uit. Ironies genoeg, vanuit historiese oogpunt beskou, was Palestina waarskynlik beter daaraan toe onder Herodes as in enige ander tydperk tydens die Romeinse era. Meer oor Herodes: P J J Botha, “Herodes - die Grote?” HTS 51/4 (1995), 996-1028; E Netzer, "Herod's building projects: state necessity or personal need?" in: The Jerusalem Cathedra: studies in the history, archaeology, geography and ethnography of the land of Israel, vol I, edited by L I Levine, Jerusalem 1981, 48-61.

27 "...subsistence technology ... is the single most important cause of the totality of differences among societies", Lenski, Lenski, and Nolan, Human sociefies, 83. Kyk verder T F Carney, The economies of antiquity: controls, gifts and trade, Lawrence 1973 . 'n Oorsig van relevante navorsing is te vinde by D E Oakman, "The ancient economy", in: R L Rohrbaugh (ed), The social sciences and New Testainent interpretation, Peabody 1996, 126-43.

28 Lenski, Lenski, and Nolan, Human societies, 178-81; MacMullen, Roman social relations: 50 B.C. to A.D. 284, 1-27; P Garnsey, Fainine and food supply in the Graeco-Roman world: responses to risk and crisis, Cambridge 1988, 43-68.

29 Daar is baie moontlike verwysings. Kyk, byvoorbeeld, Lenski, Lenski, and Nolan, a w, 178; Carney, Shape, 101-02; Horsley, Galilee, 91-92, 140-44, 177-78.

30 J D Crossan, "The life of a Mediterranean Jewish peasant", CCen 108/37 (1991), 1194.

31 Verskeie antropologiese studies van Mediterreense en ander landvolk-gemeenskappe bied baie insiggewende kruis-kulturele vergelykingsmoontlikhede: J Du Boulay, Portrait of a Greek mountain village, Oxford 1974, 3-14, 201-31; M J Herskovits and F S Herskovits, Trinidad village, (reprint 1947), New York 1976; D D Gilmore, The people of the plain: class and community in lower Andalusia, New York 1980; Barbara C Aswad, "Key and peripheral roles of 
noble women in a Middle Eastern plains village", Anthropological Quarterly 40 (1967), 139-52; J C Scott, Weapons of the weak: everyday forms of peasant resistance, New Haven 1985; Carney, aw, 111-115.

32 Kyk byvoorbeeld Filo De legatione ad Gaium 227 (en Josefus Bellum Judaicae 2.197), of let op hoe die skrywer van 3 Makkabeërs (bv 1.18) beklemtoon dat die Jode selfs in die mees drastiese omstandighede in afgesonderde geslagsgroepe optree.

33 Segregasie van die geslagte is 'n fundamentele komponent van eerste-eeuse Mediterreense, en veral van Joodse, dekorum. Hierdie segregasie is natuurlik die ommesy van die radikale patriargie wat hierdie kulture kenmerk. Bespreking: Malina, Social world, 97-120; Archer, Her price, 101-122.

34 "The pressure on the young women was inexorable. For the population of the Roman empire to remain even stationary, it appears that each woman would have had to have produced an average of five children", Brown, Body and society, 6 .

35 Die kernprobleem hier is natuurlik dat ons gegewens vir hierdie belangrike saak bykans eksklusief die aristokratiese groepe se perspektiewe en menings weergee - wat niks sê oor die erns (indien enige) van die gewone mense hiermee nie. Ek veronderstel hier ook dat daar veralgemeen kan word oor sommige aspekte van liggaamshouding in die eerste-eeuse Mediterreense wêreld. Vir 'n oorsig kyk J Bremmer, "Walking, standing and sitting in ancient Greek culture", in: J Bremmer and $\mathrm{H}$ Roodenburg (eds), A cultural history of gesture: from antiquity to the present day, Cambridge 1991, 15-35; D G Burke, "Gesture", International Standard Bible Encyclopedia 2 (1982), 449-457; S J Schultz and G L Knapp, "Postures; attitudes", International Standard Bible Encyclopedia 3 (1982), 911-912, en J E Botha, "Exploring gesture and nonverbal communication in the Bible and the ancient world: some initial observations", Neotestamentica 30/1 (1996), 1-19.

36 B J Malina, The New Testament world: insights from cultural anthropology, Atlanta 1981, 25-48, 71-90.

37 Arensburg and Smith, $a w, 1983$.

38 Antieke kleredrag: Marion Sichel, Costume of the classical world, London 1980. Wat die Romeinse era betref: D R Edwards, "Dress and ormamentation", $A B D 2$ (1992), 232-238; Larissa Bonfante Warren, "Roman costumes", ANRW 1.4 (1973), 584-614. Baie relevante inligting by R J Forbes, Studies in ancient technology, vol 4, Leiden 1964, 9-10, 31-32, 49, 58-59, 92; A H M Jones, The Roman economy: studies in ancient economic and administrative history, (edited by P A Brunt), Oxford 1974, 350-64. Vir Palestynse inligting: L Bellinger, "Cloth", IDB 1 (1962), 650-655. Daar is 'n magdom gegewens beskikbaar in S Krauss, Talmudische Archäologie. I.Bd., (reprint 1910), Hildesheim 1966, 127-207 ("Kleidung und Schmuck").

39 Klere was duur. 'n Goeie lyfrok het enigiets van 12 tot 50 denarii gekos en 'n goeie mantel 20 tot 50 denarii ('n houtwerker het 3 denarii per week verdien, wat brood vir 'n maand kon koop): D Sperber, "Costs of living in Roman Palestine", Journal of the Economic and Social History of the Orient 8 (1965), 248-271. Die rabbi's het gedink dat klere ter waarde van 50 zuz per jaar voldoende vir 'n vrou is (in Ketubboth 5.8-9). 'n Zuz is min-of-meer die ekwi- 
valent van 'n denarius: 50 zuz sou dus betaal vir 'n lyfrok en 'n eenvoudige mantel van middelmatige kwaliteit saam met ' $n$ paar lappe en miskien sandale nie veel nie, en onwaarskynlik dat dit ' $n$ jaar sou hou.

Palestynse kleinboere wat meer as een lyfrok besit het is dikwels genoodsaak om albei of aldrie gelyktydig te dra gewoon omdat daar nie bêreplek daarvoor was nie, Krauss, Talmudische Archaologie. 1. Bd, 133 n 47.

41 Daar is geen besondere bekwaamheid nodig om so ' $n$ lap te weef nie. Wat wel ' $n$ besondere lyfrok kon wees, is as die lap in 'n kruisvorm (soos 'n lang reghoek met 'n kleiner reghoek dwars daaroor) geweef is, met die kort kante vir moue. Johannes se vermelding dat Jesus se lyfrok naatloos was, het waarskynlik simboliese betekenis (kyk Joh 19:23-24); dat Jesus as priester sterf of dat wat aan Jesus behoort "een" moet wees. Johannes self beklemtoon dat die "Skrifte vervul" moet word. R E Brown, The Gospel according to John, vol 2 (xiii-xxi), AB 29A, New York 1966, 920-922 bespreek die moontlikhede.

42 Maar net priesters kon ' $n$ kleed dra waar 'n egte wollap en 'n egte katoenlap aanmekaar gewerk is. J Milgrom, "Of hems and tassels", BAR 9/3 (1983), 65.

43 Dit is die situasie van 'n pa wat sy mantel snags met sy vrou en jong kindertjies moet deel, wat die agtergrond vorm vir Lukas 11:5-8.

44 Mooi illustrasie in J N Tubb, Die wêreld van die Bybel, (translated by L Wels), Halfway House 1992, 35.

45 Wit klere was die voorwaarde vir enigiemand wat met God kontak gehad het. Dit is die vooroordeel teen vroue wat gemaak het dat hulle aangemoedig is om gekleurde klere te dra. Indien 'n vrou strepe op haar lyfrok gehad het, was dit belangrik dat dit bedek moes wees. Wol en linne is voor die weefproses gebleik deur dit te vol in komme met spesiale klei, 'n duursame en tydrowende proses, Forbes, Srudies 4, 83-87.

46 Gewoon omdat die meeste mense klere nie kon bleik en kleur nie. Die kleur van wol, linne en katoen nadat dit geweef is het gewissel van baie donkerbruin tot liggrys.

47 Die oorspronklike kleur van die wol of linne (gelerig, skakerings van bruin) bied heelwat moontlikhede saam met kleursels (saam met blou kry mens groen, saam met rooi weer oranje of pers ensomeer). Die kleurstowwe wat Palestynse kleinboere gebruik het, is meesal vanaf plante verkry: jong, onryp dadels (groen kleurstof); krapwortel en granate (rooi); granaatskille, okkemeute en terpentynboomneute (geel). Insekte is ook gebruik; 'n gogga wat op eikebome leef, lewer 'n karmosynkleursel. Nie een van hierdie mengsels is kleurvas nie. I Jacob and W Jacob, "Flora", $A B D 2$ (1992), 803-17. Blousel is verkry vanaf die indigoplant en bloubosbessie (whortleberry). Die kleurstowwe is, nadat dit gemeng en voorberei is, ingeweek en met groot ronde klippe in die materiale ingestamp. Die "handel" van bloukleursels was destyds baie groot besigheid: $\mathbf{M}$ Reinhold, History of purple as a status symbol in antiquity, Collection Latomus, vol. 116, Brussels 1970, 51 vv, 53 n l; Forbes, Studies 4, 120.

48 Die statigste en mees pretensieuse drag was 'n spierwit linne lyfrok met 'n helder pers wolmantel (cf. Luk 16:19). Die sogenaamde "koninklike pers" van die antieke wêreld kan na enigiets van donkerrooi tot diepblou verwys, insluitende die verskillende skakerings van pers. Egte Tireense pers (vervaardig van skulpdiertjies) was ontsaglik duur, sowat R800 'n gram. Reinhold, $a w, 1970$; Milgrom, $a w, 1983,63$. 
49 Pesch, a w, 366; Milgrom, a w, 1993; P J J Botha, “Jesus the Jew: some reflections on current investigations", Religion \& Theology 1/2 (1994), 185 209.

50 Meer oor baarde in die antieke, vergelyk $G$ Colbow and $R$ Hurschmann, “Bart", Der Neue Pauly: Enzyklopüdie der Antike 2 (1997), 456-58. 